\title{
Traditional seed processing and storage: A need to retain minimum crop diversity in India
}

\author{
Rishi Richa*1, P. K. Omre ${ }^{1}$ and Rajeev Shukla ${ }^{2}$ \\ ${ }^{1}$ Post Harvest Process \& Food Engineering, College of Technology \\ ${ }^{2}$ Deptt. of Agronomy, College of Agriculture \\ G.B. Pant University of Agriculture and Technology, Pantnagar-263145 (Uttarakhand), India \\ *Email: rishi.richa@rediffmail.com
}

\begin{abstract}
Tremendous loss in genetic diversity has been noticed across the globe during last century. India use to nearly 200000 rice varieties or even more have declines to a two digit numbers only. According to FAO estimates nearly $75 \%$ of genetic diversity of crop plants was lost in last century. Suitable land races decide the direction of resistant breeding programmes. Major pest epidemics of the country fought with the resistance found in the landraces of USA wheat in 1904 and 1917, Indian rice in 1943, USA oats in 1940s and 50s and Soviet wheat in early 70s. In year to come, more economy concerns will arise at global level and major sufferer will be the developing and under developed nations with agriculture based economy. Green revolution is the main culprit for erosion of landraces. Government of India realized the need for preserving plant genetic resources of the country. Present paper discusses the possibility of restoring and maintaining minimum plant genetic pool in its natural conditions through traditional seed processing, storage and renewal/growing of crops under natural conditions in suitable agro-climatic zones.
\end{abstract}

Keywords: Storage, seed processing, crop diversity, straw bin, seed bank.

Paper cited: Richa, R., Omre, P.K., and Shukla, R. (2015). Traditional seed processing and storage: A need to retain minimum crop diversity in India. South Asian J. Food Technol. Environ. 1(2):160-166.

The dependence of humankind on plant resources is well understood. Since the beginning of agriculture, domestication and gathering of desired plant species have helped in the evolution of useful plant species and these resources have been exploited for human development. Out of the 75,000 species of edible plants (Gautam and Singh, 1998), only about 150 have been widely used. Out of these about 30 species provide $90 \%$ of the world's food. Economically less important or low yielding crop varieties are vanishing. There had been tremendous loss to genetic diversity over the globe in last few decades. Indian farmers used to grow more than 30000 rice varieties over the past 50 years matching to its soil, climate, crop rotation and social requirement. During year 2005 nearly $75 \%$ of rice area was covered with only 10 rice varieties. According to FAO estimates nearly $75 \%$ of genetic diversity of crop plants was lost in last century. About $97 \%$ of genetic resources of US have been lost in last 80 years. Mexico lost about $80 \%$ of its maize varieties. Philipino farmers once used to grow thousands of rice varieties, growing now only two rice varieties in $98 \%$ sown area. Out of 8000 rice varieties in China grown during 1949 was left with only 50 varieties during 1970 . Breeding programmes use to re-insert resistance often rely upon landraces. Major pest epidemics of the country was fought with the resistance found in the landraces of USA wheat in 1904 and 1917, Indian rice in 1943, USA oats in 1940s and 50s and Soviet wheat in early 70s. There had been loss of genetic base of crop varieties to such an extent that top breeders are using same genetic materials. There is a need to preserve plant genetic resources at farmer's field with available traditional knowledge.

\section{Indigenous crops of India}

There are 49 major and minor crops endemic to the country. This includes rice, four minor millets, four pulses, Indian mustard, nine vegetables, five tuber crops, eleven fruits, five spices of sugarcane, seven fibre crops and Cannabis (medicinal plant). Plants having India origin are Oryza sativa, rice; Eleusine coracana, African millet; Cicer arietinum, chickpea; Phaseolus aconitifolius, Mothbean; Phaseolus calcaratus, ricebean; Dolichos biflorus, Horsegram; Vigna sinensis, Asparagus bean ; Solonum melongena, eggplant; Raphanus caudatus, Rats tail radish; Colocasia antiquorum, Taro yam; Cucumis sativas, Cucumber; Gossypium arboreum,Tree cotton 2x; Corchorus olitorius, Jute; 
Piper nigrum, Pepper, and Indigofera tinctoria, Indigo.

The list of Food Crops of the World, Published by the World Conservation Monitoring Centre in 1992 includes following crops as having Indian origin: Mangifera indica, Mango; Colocasia esculenta, taro; Camellia sinesis, Tea; Brassica juncea, Mustardseed; Cucumis sativas, Cucumber; Eleusine coracana, Fingermillet; Oryza sativa (O.nivara), Rice; Cajanus cajan, Pigeonpea; Sesamum orientale, Sesame seed; Piper nigrum, Pepper ; Malus pumila, Apple; Prunus communis, Pear; Citrus limon, Lemon; Solanum melongena, Eggplant; and Elettaria cardamomum, Cardamom.

\section{Crops introduced in India}

The presently cultivated plants have been derived from two sources, (1) indigenous, and (2) introduced. Plant genetic materials brought from various continents and countries, namely, Western Asia, Africa, China, Southeast Asia and Pacific Islands. The new crops introduced in the country over the past few centuries by Moughals and the Spanish, Portuguese and British voyagers include apple, pear, peach, apricot, grape, almond, datepalm, maize, potato, sweet-potato, tomato, beans, onion, garlic, chillies and lentil. In due course, the introduced crop species had naturalized and adapted, and consequently these have become integral part of the Indian agriculture. Literatures quote that the Arabs possibly brought with them clove, coriander, cumin and fennel but does not seem correct as use of these items are well documented in traditional rituals.

British occupation led to the introduction of coffee, cocoa, cashew nut, litchi, cinchona, strawberry and blueberry. Tea was introduced from china and rubber and pineapple from Latin America.

India is having a long history of agriculture. Archaeological evidences suggested that rice, wheat and barley cultivation were already widespread in India by the year 2000 BC. Archaeological records of different crops depict an ancient occurrence of the crops such as barley, Hordeum; bajra, Pennisetum; caster, Ricinus; date-palm, Phoenix; horsegram, Dolichos; jower, Sorghum: lentils, lens: linseed, linum; maize, Zea; melon, Cucurbita; mung, Phaseolus; peas, Pisum; amla, phyllanthus; kodo, paspalum scrobiculatum; ragi, Eleusine;rice, Oryza; sesame, Sesamum; wheat, Triticum; and ber, Ziziphas, besides some weed seeds.

Archaeological evidences state about presence of crop but not since when it is prevalent.

Mythological literatures must be also looked for such findings. For example Maharshi Valmiki
The introduced and naturalized species have undergone process of diversification. There is now preponderance of variable landrace forms/primitive types belonging to different crop groups such as cereals, millets, legumes, vegetables, fruits, forages, fibres, sugar-yielding types, spices, condiments, medicinal and aromatic plant and others grown in diverse phyto-geographical and agro-ecological regions of the country.

\section{Efforts for restoring biodiversity}

Efforts through 21 centres of NBPGR located in different agro-climatic zones of India for germplasm build-up, maintenance and evaluation of prioritized underutilized crop plants are being made. The objectives of this programme are outlined below.

- To find new plant resources for food, fodder and industrial uses.

- To build up an extensive germplasm collection and to characterize, conserve and enhance them.

- To identify/develop high yielding varieties of these crops for different farming situations.

- To evolve an appropriate package of agronomic practices for their economic cultivation.

- To disseminate knowledge about potential species for their popularization.

Global Plan of Action covers 20 activities for conservation of plant genetic resources. India has given due attention to most of the activities. Priorities have been enhanced over the time. Table 1 shows the enhanced priority of biodiversity conservation.

\section{Archaeological and pauranik evidence of agriculture in India}

wrote in the Ramayan that Lord Ram, Bhagwati Seeta and brother Laxman are passing through matured rice fields on the way of Van. The time of Ramayan is Tretayug. Mahrashi Valmiki has further written that at the end of Satyuga, Tretayug comes when agriculture appears on the earth with first foot of Anrit (Asaty). When you start agriculture you have to go for storage and storage a symbol of wealth. First storage "wealth" means emergence of greed that is loss of innocence and piousness. Adams Eve story is narrated on this line. All the four Yug have 5000 years of life. Kaylug is going to end shortly. 5000 years of Kalyuga is going to be over and 5000 years of Dwapar is already gone. If on conservative side mid of Tretayug is taken as incarnation of Lord Ram. Then total time becomes 5000 (Kalyug) +5000 $($ Dwaparyug $)+2500($ Tretayug $)=12500$ years. 
Table 1: Priority for conservation of biodiversity in India

\begin{tabular}{|c|c|c|c|c|}
\hline \multirow[t]{2}{*}{ S.N. } & \multirow[t]{2}{*}{ Conservation measures } & \multicolumn{3}{|c|}{ Time changing priority } \\
\hline & & 1996 & 2001 & 2005 \\
\hline \multirow[t]{5}{*}{1.} & In-situ conservation and development & & & \\
\hline & $\begin{array}{l}\text { Surveying and inventorying plant genetic resource for food } \\
\text { and agriculture }\end{array}$ & $* * *$ & $* * *$ & $* * *$ \\
\hline & $\begin{array}{l}\text { Supporting on farm management and improvement of } \\
\text { plant genetic resource for food and agriculture }\end{array}$ & $* *$ & $* *$ & $* * *$ \\
\hline & $\begin{array}{l}\text { Assisting farmers in disaster situations to restore } \\
\text { agricultural systems }\end{array}$ & $*$ & $* *$ & $* *$ \\
\hline & $\begin{array}{l}\text { Promoting in-situ conservation of wild crop relatives and } \\
\text { wild plants for food production }\end{array}$ & $*$ & $*$ & $*$ \\
\hline 2. & Ex-situ conservation & & & \\
\hline 3. & Utilization of Plant Genetic Resources & & & \\
\hline 4. & Institutional capacity building & & & \\
\hline
\end{tabular}

(Source: NBPGR Reports)

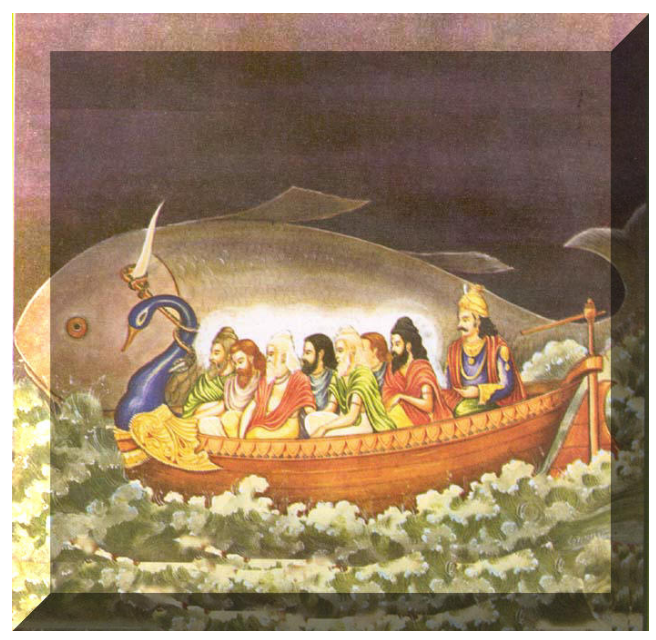

Fig. 1: Traditional Knowledge for Plant Genetic Resources Conservation

It means in India at least 12500 years ago rice cultivation was in practice. Another mythological (Pauranik) story tells that Rajarshi Vishwamitra made wheat (his own cereal) to create a parallel Swarg for King Satyvrat (Trishanku-named after the curse of Vramarshi Vasishht). He made his first cereal i.e. wheat. Now plant breeders know it well that wheat is having three distinct characters in its gene. This emphasizes the importance of breeding and developing new crop varieties.

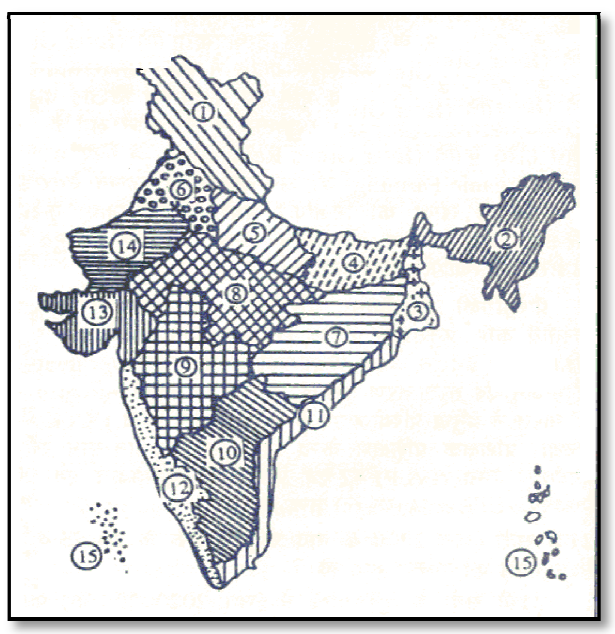

Fig. 2: Agro-climatic zones of India

\section{Matsyavtar for conservation genetic resources}

The first incarnation of Lord Vishnu was in form of fish to protect genetic resources. The Katha goes like this. One day Lord Manu after his worship routine was offering water in his palms (called Arghya) to the Sun. At that time he heard a subtle voice: Manu! Look at Me, I need your help. Manu saw a small fish in his palms and the voice manifested from the fish. Manu said, You seem to be a divine personality. Tell me, how can I serve You? 
The fish said, I wish to execute a gigantic task but this pond is very small for it. Thus do take me to the river Ganges. Lord Manu's heart overflowed with love when he heard the voice of this divine fish. Hence he took the divine fish in his water-pot and took it to a large river. On another auspicious occasion Lord Manu again visited that place and he again beheld that divine fish. The divine fish said: My size is increasing. Hence help me reach the ocean. Manu obliged and took the fish to the ocean. The Fish in her last meeting with Manu told him that there is going to be Jal Pralya, so collect seed materials for all possible plants and Vedas (pool of knowledge) and come to me. Suddenly there was Jala-Pralaya (destruction of the world by a deluge). In that destruction everything was getting destroyed and the Fish took Manu and seven Rishis (Saptarshis) to Himalya on its back. This is the first story of protecting genetic pool for the welfare of human societies.

Advanced technology based conservation techniques for plant genetic resources have its own merits and demerits. In conserving plant genetic resources traditional seed processing, seed storage and crop management all together has important role to play. Crops having limited market and economic values are endangered if government efforts is not paid at due time. Such crops with very high tech based storage with no or limited access to the farmers that too without old traditional technology and economic loss has risk for failure. Incentive based and market driven strategies will be helpful in conserving plant genetic resources at farmers' field with living old technology. High tech based strategies may lead to failure or non reversible loss. Following steps are suggested to revive old technology and keep it alive for conserving and managing plant genetic resources.

Selection of Typical Area: Whole country is divided into 15 agro-climatic zones as shown in Fig. 2. A clusters of 4 to 5 villages need to be identified in each agro-climatic zone typically representative of the climate of the region. The selection of villages should be done by the agricultural university of the state/region keeping several points in mind. A group of scientists mainly breeder, agronomist and seed technologist should be assigned the task of biodiversity conservation and management.

Selection of Farmers: After selecting five to ten representative clusters of villages in a given agroclimatic region, four to five farmers should be selected from each village. A general awareness and training must be given to the farmers to brush up their mind for setting importance of their works. A detailed survey of the area must be conducted and elderly person must be interrogated to know the vegetation and vegetative pattern of the area 50 to 80 years before to compare the scenario. Identifications of Plant Genetic Materials to be conserved: Plant genetic materials of the area having special characters need to be preserved and protected should be identified through a national committee. Seed and plant materials should be now collected from the area. Each crop must have one 0.25 to 1.0 hectare of crop stand. Large tree materials can be preserved along the rural or state and national highways. Instead of planting exotic tree plant sapling local trees, fruits plantation must be preferred. One road may be named only after a specific plant type by planting it along the road.

Collection of Traditional Knowledge Pool for Each Crop: Traditional knowledge pool related to each crop right from its specific use, seed collection, processing, storage, plantation/seeding and agronomic practices must be collected interrogating elderly person. Collected information must be documented. Traditional knowledge base can be enriched and modified with scientific input. Minimum efforts should be given to the high tech interventions.

Ensuring Markets: A market need to be developed for traditional low economic value crop which may fetch high price than the traditional crops. Processing, storage and marketing strategies should be evolved to self sustain the agricultural production system. If required city based market could be also looked for self sustenance. There exists market but need to be channelized.

Ensuring Minimum Market Price for Prevailing Common Crops: If at all required government should plan to pay deficit amount from for the preserved crop and prevalent crop from a unit area. This will minimize the cost of conservation and management.

\section{Traditional Seed Collection, Processing and Storage}

Traditional seed collection, processing and storage will remain the back bone of preservation and management of plant bio-genetic resources. If economics works out well, it will spread in adjoining area automatically and seed will be required. A sample of traditional seed storage techniques is given below:

1. Red Gram Storage with Common Salts: Farmers mix about $200 \mathrm{gm}$ of common salts available at their home with one kilogram of red gram grain (pigeon pea) manually. Treated grain is then stored in jute gunny bags by stitching it. Insects remain away from the grain and it is safe of 6-8 months. 
2. Ash Seed Treatment in Sorghum: Ash is mixed with sorghum seed at the ratio of 1:4. After the ash treatment sorghum seeds were tied airtight in the jute gunny bags. Farmers believed that this technique can keep grains away from insect and pest for about six months.

3. Ragi Storage with Neem and Thumbai Leaves: Ragi is the main food grain crop grown by many people specially in the dry area. Farmers used neem leaves and thumbai leaves in the storage of ragi. The strong odour of these leaves keeps the storage pest like lesser grain borers, saw toothed beetle and flat grain beetle. It is very cheap and simple. Most of the farmers follow this technique to get rid of storage pest than to rely on costlier chemical treatment. Neem leaves and thumbai being organic repellent are safe to use.

4. Paddy Storage: Farmers are storing paddy grain in a granary room known as Macchu. The Mcchu is located in the corner of house and at a height of nearly two meter from ground. The platform of room is made of wooden board and sides are made of brick and cement. It has an opening or a net protected door for ventilation. Grain is spread over the platform and an earthen pot filled with $3 / 4$ water is kept inside granary room which attracts rice moth and kills it. Grains remain dry due to no contact with ground and rat free.

5. Storage of Grain Using Camphor: Farmers use to keep one gram of camphor in five kilogram of grain put in jute gunny bags. The camphor acts as repelling agent for insects and pests. Grain is safe for about three months then again it need to be sundried and putting fresh doze of camphor in it.

6. Storage of Seeds With Lime: Farmers use to store pulse grain with lime powder. Farmers used dust 10 $\mathrm{gm}$ of lime in one $\mathrm{kg}$ of grains. After thorough mixing, grain is stored in jute gunny bags. Lime imitate irritating odour and repels insects. Grain can be stored for whole year.

7. Gingelly Seed Storage: Storage of oil seeds is more critical. Farmers use to mix $100 \mathrm{gm}$ of rice in the storage of gingelly seeds. Indian meal moth which is main insect causing damage by webbing the gingelly seeds by secretion. Rice having sharp edge do not allow moth larvae to web with gingelly seed.

8. Neem Oil in Seed Storage: Farmers use to mix 20 $\mathrm{ml}$ of neem oil with one $\mathrm{kg}$ of pulse seed and after proper mixing store it. Neem oil acts as repellent for Weevil red flour beetles, long headed flour beetle and fig moth. Neem oil also destroy a variety of insects attacking legumes at the egg stage.

9. Neem Seed Kernel Extract Dip Jute Gunny Bag: Farmers treat jute gunny bags by dipping it in neem kernel extract solution (10 $\mathrm{kg}$ of powdered 2015 ( ) Society for World Environment, Food and Technology neem seed kernel +100 liter of water). These gunny bags are used to store paddy, pulses and oil seeds.

10. Storage of Vegetable Seeds with Cow Dung: Vegetables seeds such as bitter gourd, bottle gourd and ash gourd etc. are put inside the fresh cow dung and then sun dried for 2-3 days. After thorough drying, seeds are stored for a year or so for next planting. Farmers believe that cow dung has pesticidal property. Germination percentage of the seed is higher compared to other method of storage.

11. Pungum Leave for Paddy Storage: This is age old practice. Fresh pungam leaves (Pongamia globra) are placed as a layer between gunny bags. The leaves act as repellent against Angoumois grain moth and rice weevils. It also avoids pest attack.

12. Mud Pots in Grain Storage: Quite common over the country. Seed materials are kept in mud pot covered with lid and sealed with mud and then it is placed over a circular mud ring. This avoids moisture entry in the pot. Stored grain is taken out after 3-6 months, sun dried and again refilled in pots and kept back.

Similarly there is large number of traditional storage techniques locally available in each agroecological zone. These techniques need to be collected urgently, documented and disseminated to the researchers and farmers of country for further use and improvement with locally available cheaper materials.

\section{Conclusions}

Depleting plant genetic resources is an alarming call for the agricultural scientists and planners and government. Efforts are being made for preserving and conserving plant genetic resources at different levels. Typical traditional rice, wheat, mustard, vegetables and fruit varieties had disappeared from the genetic pool. Traditional knowledge based preservation and conservation of local plant genetic resources through farmers' participation is the need of the day. Traditional seed collection, processing and storage will retain minimum crop biodiversity in the country.

\section{References}

1. Handbook of Agriculture (2006). An ICAR Publication. Directorate of Information and Publication of Agriculture, ICAR, New Delhi.

2. Gautam, P.L. and Singh, A.K. (1998) Agrobiodiversity and Intellectual Property Rights (IPR) related issues. Indian J Plant Genetic Resources. 11(2): 129-151.

3. Karthikeyan, C; Veeragavathatham, D., Karpagam, D. and Firdouse, S.A. (2009). Indian J Tradit Knowl. 8(4): 564-568. 

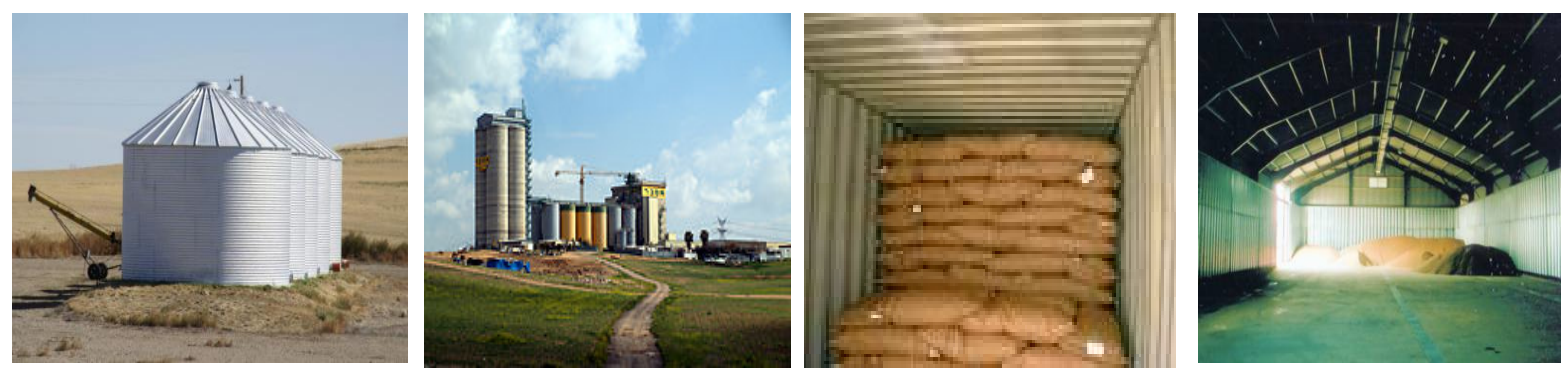

\section{Modern Storage}
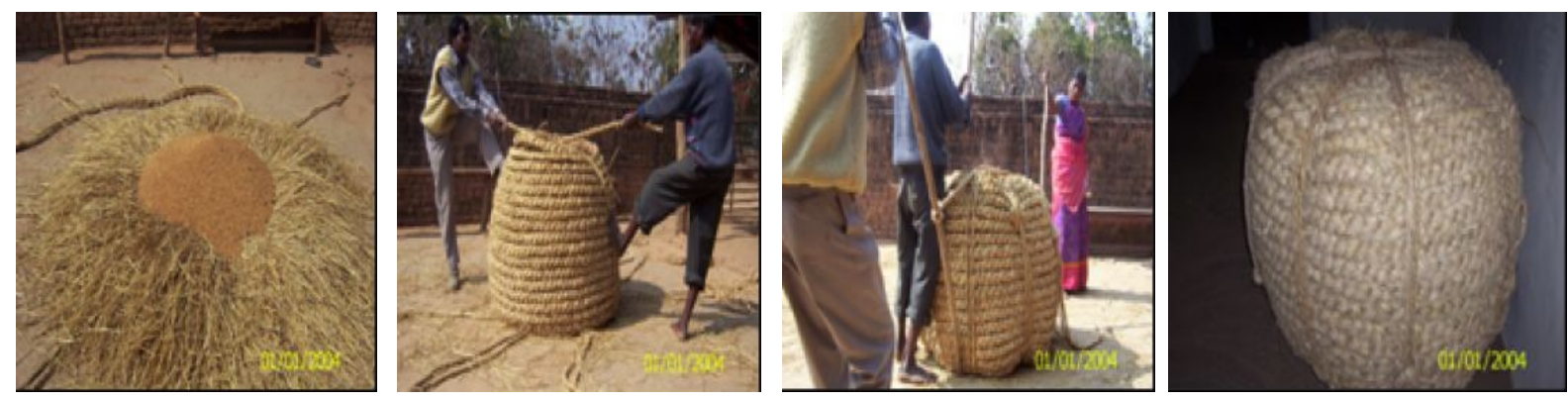

\section{Straw Bin}
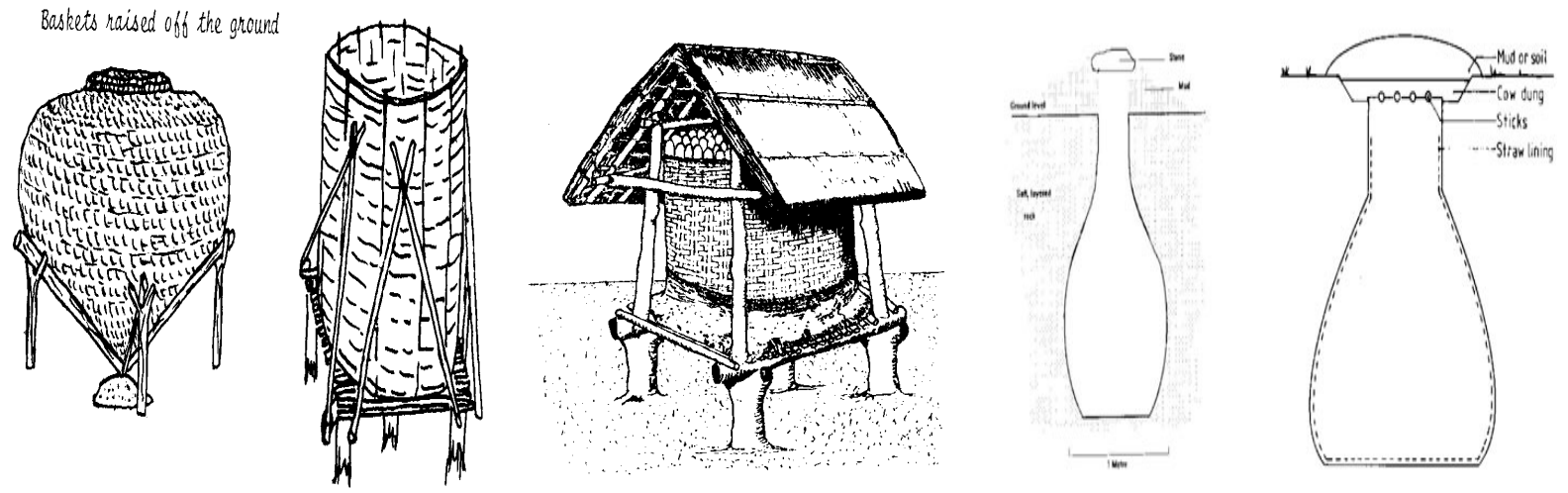

Basket Raised off the Ground

Basket Raised off the Ground Covered with Thatched Roof

Under Ground Bin

\section{Under Ground Bin}




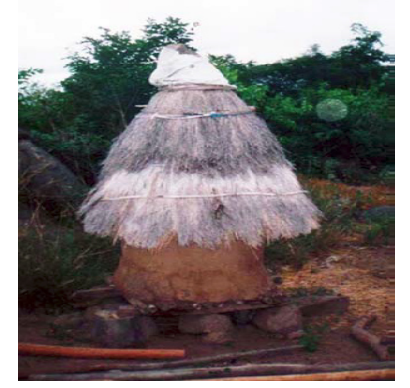

Bamboo Bin

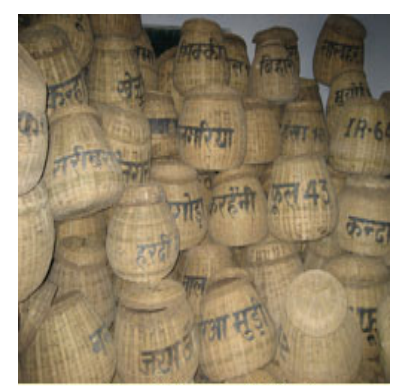

Covered Basket

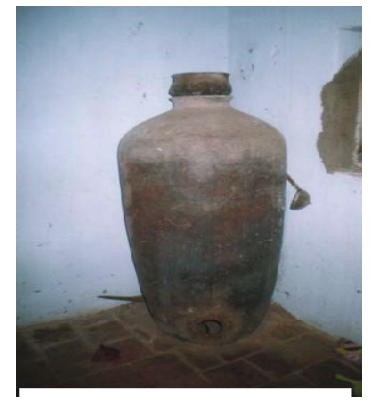

Earthen Bin

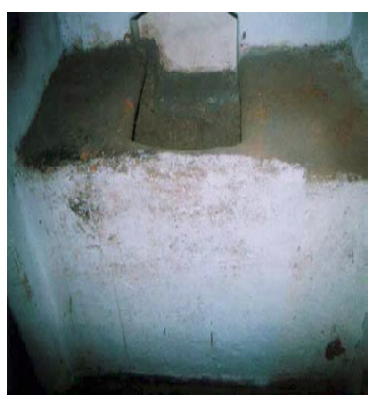

Mud Chamber

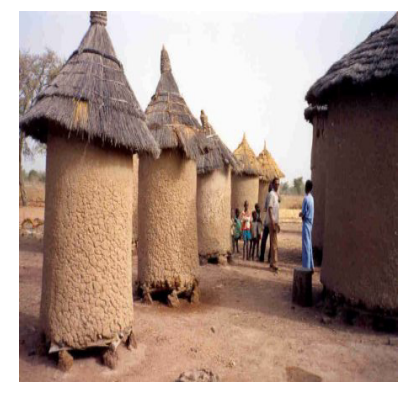

Series of Bamboo Bin

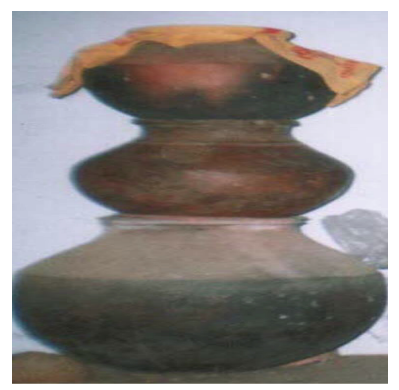

Earthen Pot

\section{Seed bank}

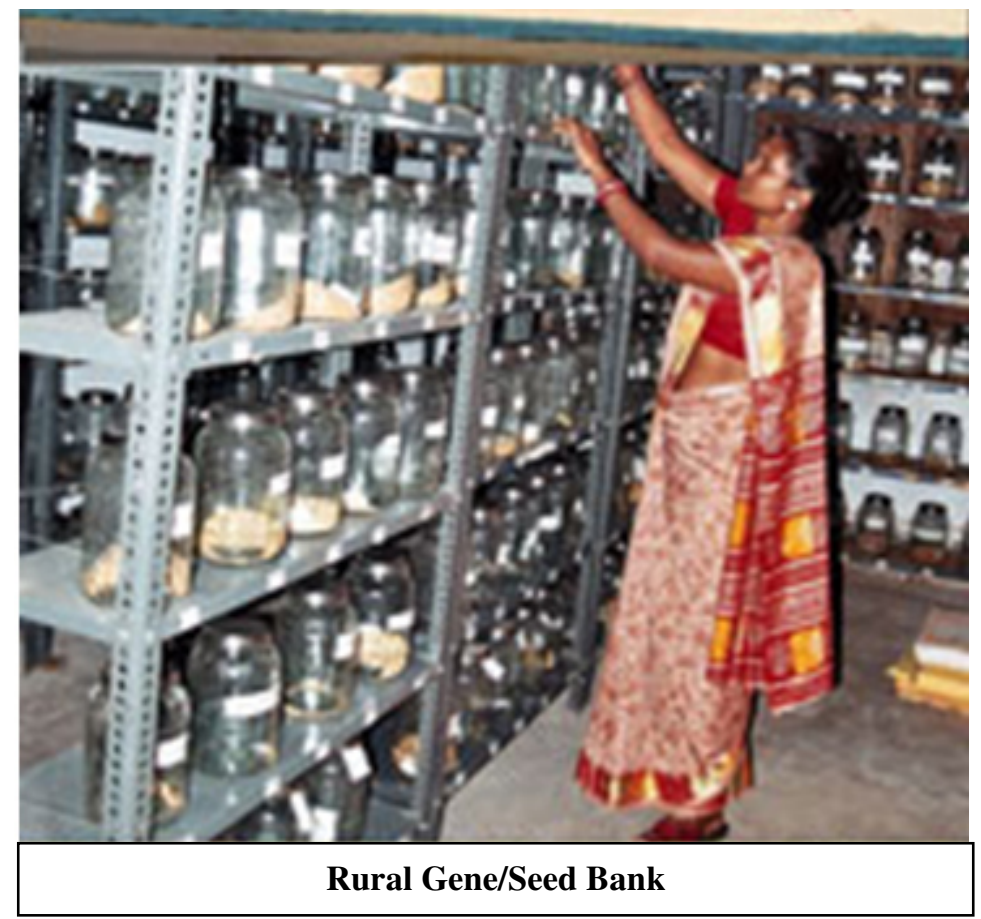

